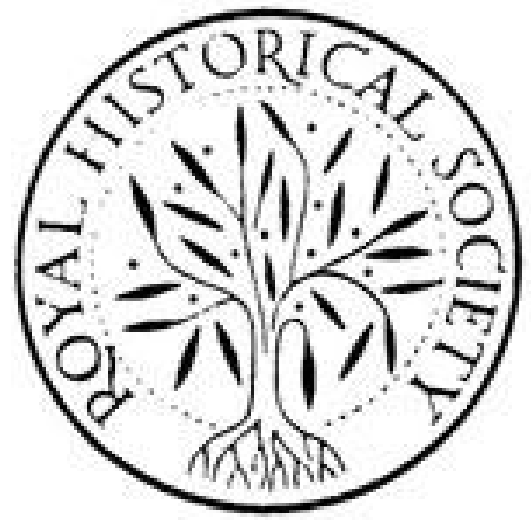

The Trial of Sir Walter Raleigh: A Lecture Delivered in Connection with the Raleigh Tercentenary Commemoration

Author(s): Harry L. Stephen

Source: Transactions of the Royal Historical Society, Vol. 2 (1919), pp. 172-187

Published by: Cambridge University Press on behalf of the Royal Historical Society

Stable URL: http://www.jstor.org/stable/3678257

Accessed: 27-06-2016 09:10 UTC

Your use of the JSTOR archive indicates your acceptance of the Terms \& Conditions of Use, available at

http://about.jstor.org/terms

JSTOR is a not-for-profit service that helps scholars, researchers, and students discover, use, and build upon a wide range of content in a trusted digital archive. We use information technology and tools to increase productivity and facilitate new forms of scholarship. For more information about JSTOR, please contact support@jstor.org.

Cambridge University Press, Royal Historical Society are collaborating with JSTOR to digitize, preserve and extend access to Transactions of the Royal Historical Society 


\title{
THE TRIAL OF SIR WALTER RALEIGH
}

A Lecture delivered in connection with the Raleigh Tercentenary Commemoration

\author{
BY SIR HARRY L. STEPHEN
}

THE subject of my paper is the trial of Sir Walter Raleigh. I propose to confine what I have to say to that subject, and consequently to consider legal rather than historical matters, as far as the two can be distingished, but I hope that some of my audience may deal with the points that I may have to notice from that wider point of view which it is so necessary to take into account if our national system of law is to be properly appreciated.

The trial took place at Winchester on November I 7 , I 603, of which to-morrow may be considered the i i 5 th anniversary if we take the change of style into account. Before noticing the legal points that I wish to bring to your notice I will attempt to make an analysis of the trial itself from the point of view of a modern lawyer taking on himself the function of a critic with a revisionary jurisdiction.

The indictment charged Raleigh with high treason by conspiring to deprive the King of his Government ; to alter religion; to bring in the Roman superstition; and to procure foreign enemies to invade the kingdom. The facts alleged to support these charges were that Lord Cobham on June I I, I603, the previous June that is, met Raleigh at Durham House, where the Adelphi now stands, and conferred with him as to advancing Lady Arabella Stuart to the throne; that it was there agreed that Cobham should bargain with Aremberg, the 
Ambassador of the Archduke of Austria, for a bribe of 600,000 crowns ; that Cobham should go to the Archduke to procure his support from the King of Spain ; that Lady Arabella should write three letters to the Archduke, to the King of Spain, and to the Duke of Savoy, promising to establish peace between England and Spain, to tolerate the Popish and Roman superstition, and to be ruled by them as to her marriage. Cobham was then to return to Jersey where he would find Raleigh and take counsel with him as to how to distribute Aremberg's bribe. On the same day Cobham told his brother Brook of all these treasons and persuaded him to assent to them ; afterwards Cobham and Brook spoke these words, "that there never would be a good world in England till the King (meaning our sovereign lord) and his cubs (meaning his royal issue) were taken away". Further Raleigh published a book to Cobham, written against the title of the King, and Cobham published the same book to Brook. Further Cobham, on June I4, at Raleigh's instigation, moved Brook to instigate Lady Arabella to write the letters as aforesaid. Also on June I7, Cobham, at Raleigh's instigation, wrote to Aremberg through one Matthew de Laurency, to obtain the 600,000 crowns, which were promised to him on June 18 , and of which Cobham promised 8000 to Raleigh and I0,000 to Brook.

To this Raleigh pleaded not guilty; and the case was opened by Neale who confined himself to the indictment; and by Coke. The actual charges made by the latter are that Raleigh had conspired with Cobham that the latter should receive the King of Spain's money to be distributed by both of them among the discontented, and that he had supported the claim of the Lady Arabella to the throne. His speech contained matters of prejudice such as the Bye or surprising treason, the leading men in which had been convicted two days before, matters of suspicion such as the correspondence with Cobham imputed to Raleigh, a good deal of inevitable pedantry, characteristic 
both of the speaker and the period, and of course much of the rancorous ferocity that characterised the whole of Coke's conduct on this melancholy occasion. The report of it that we have is no doubt very much abbreviated, sometimes clumsily enough; but it is plain that Coke knew that Cobham's "confession" was the only ground on which he could possibly hope to obtain a conviction. That Brook said that Cobham said, that Grey and others were in the Bye, but he and Raleigh were in the Main; and that Raleigh had in his possession a document impugning the King's title, were facts which if true did not add much more to the case than the statement of a "Portugal gentleman" that Don Raleigh and Don Cobham would cut the King's throat before he could be crowned; and these are all the matters that, whether we regard them as evidence or not, can be regarded as relevant. The case depended therefore on the examinations of Cobham and of Raleigh himself.

The text of these examinations is not available, and from Professor Gardiner's account of the trial and other authorities the best account of them we have appears to be that in Howell's State Trials. There they are in oblique oration, and look like a very much summarised note of what must have been a long proceeding. The first of these shows that Cobham began by oaths and exclamations against Raleigh imputing to him the instigation of his proceedings. He states that he intended to go to the Archduke "to confer with him about these Practices"; that he intended then to go to Spain to get the 600,000 crowns, and afterwards to meet Raleigh in Jersey to consider about their distribution. He spoke with Raleigh about plots and invasions of which no particulars were given; and professed that he did not in fact trust him. At a subsequent examination, Raleigh's letter to Cecil revealing Cobham's dealings with Aremberg, written after he had been consulted or examined about the Bye Plot, were shown to Cobham, and he repeated what he had said 
before. At the same, or possibly at another time, he told the story of a letter from Raleigh brought by Kemish to him in the Tower in which Raleigh said that he had cleared himself, and of a message from Raleigh that he was to " be of good comfort for one witness could not condemn a man for treason". Finally came the letter produced by Coke at the end of the trial in which Cobham confessed to having carried on correspondence with Raleigh while he was in the Tower, which ended by his retracting his statement that he was to meet Raleigh at Jersey, on his way home from Spain, and possibly other charges he had made to Raleigh's detriment, and concluded with the statement that the latter was to receive a pension of $£ 1500$ from Aremberg in consideration of preventing action against Spain; a matter not referred to in the indictment. On the other hand, Cobham retracted his second statement-this is how I understand it- " before he came to the stair foot," though how complete this retractation was is not stated, and he admitted in his letter to Raleigh, produced as a reply to the letter produced by Coke, that he had never practised with Spain by Raleigh's procurement. All that Raleigh's admissions came to is that he was intimate enough with Cobham for the latter to offer him 8000 crowns for furthering peace with Spain, a matter which he treated as an idle conceit.

Such was the case made against Raleigh when reduced to its elements and shorn of all. the picturesque features imputed into it by the characters and the passions of the parties concerned. So reduced, it is unnecessary to dwell on the point that apart from all question of procedure and making all possible allowances for the changes which time has produced in our views about the spirit in which criminal proceedings should be conducted, it was no case at all. It supports the general charges in the indictment only by the vaguest possible reference to "these practices," and "plots and invasions" of which no more is said. The publication of Raleigh's book is made 
to appear as one of those mare's nests, which prosecutors of to-day are above all things anxious to keep out of their indictments, and if there was ground for supposing that Raleigh agreed to take a pension from Spain, which does not seem to be the case, that was a far weaker foundation for a charge of treason than a similar act would be to-day. Moreover all the evidence supporting the case came from Cobham, who, besides being an accomplice, failed to stand any of the tests which under any system of enquiry can be applied to a witness. Under these circumstances it is not worth while to go into the matter in detail; and all that I feel called on to say about the result of the trial is that it throws no light on the question whether Raleigh was in fact guilty of treason, except in so far as it may be said that the Government strained every nerve to make a case against him, and completely failed to do so. What other evidence there may be as to Raleigh's actions at the time of his fall is not a question for me to consider. The Government no doubt had a considerable body of information in their possession, which their peculiar relations to the Catholics, the Jesuits in particular, and to the King of Spain and Aremberg, made it impossible for them to produce, and some of it may have been relevant to Raleigh's guilt; but I understand that since the date of the trial nothing has come to light to show that Raleigh's conviction was not as unjust as has always been popularly supposed. I have therefore no wish to question the view of the verdict that seems to have prevailed since it was given. But if I have to admit that English administration of justice grossly failed on this occasion there can be no doubt that the reaction was immediate and that, at least from that time on, the essential features of what we consider justice in such matters were gradually developed on consistently progressive lines. The process was slow enough; but it was at least continuous.

The whole trial was based on procedure that has survived to our times. The Court was constituted as it 
might be to-day under a Commission of Oyer and Terminer. It consisted of seven persons of good position and four judges. With a slight difference in the proportion of laymen to lawyers the same might be said of any Court of Assize, so called, of the present day. The indictment was presented, I suppose by a Middlesex Grand Jury, at Staines, and the trial would normally have taken place in the King's Bench in London, but, because of the prevalence of the plague there, was moved to Winchester, where it took place in Wolvesey Castle. The jury were, it is said, Middlesex men, and Raleigh was offered, but did not accept a right of challenge. So far the form of the proceedings is as modern as is to be expected in proceedings more than 300 years ago. The substance, however, was as different as may be. To-day the lay Commissioners, if they were present at all, which most of them probably would not be, would be local Justices of the Peace selected for their social or political importance in the country; and they would be mere spectators of the proceedings. Then they were among the most important politicians of the day, and must all have been personally deeply interested in the result. Lord Henry Howard, afterwards Earl of Northampton, was notoriously hostile to Raleigh ; Cecil, Waad and he had taken an active part in preparing the case, the first two in fact probably knew more about it than any one else, and Cecil took a leading part in its conduct. The judges were much as they might be in a trial of political importance to-day, and whatever may be said as to their independence or fairness, it is plain that Popham, the Lord Chief Justice, kept the conduct of the trial well in his own hands. But at this point it must be admitted that the likeness to modern proceedings, or anything that we consider to be a fair trial, ceases. It began in the way that we are familiar with, by the opening first of the indictment and then of the case; but this degenerated at times into recriminations between prosecuting counsel and the prisoner, the TRANS. 4 TH S.-VOL. II. 
nature of which vigorously survives in the pages of Howell. When the evidence, such as it was, was introduced, arguments on both sides continued. The Commissioners interrupted at their discretion, and in Cecil's case with considerable effect, and occasionally gave evidence and explanations of matters of fact. At the same time, as I have said, the Lord Chief Justice seems to have kept his hand in the proceedings throughout, though he did not sum up, and in fact never formally addressed the jury at all. The trial thus openly, and to a high degree, assumed the form which is in fact essential to all English trials, and became a duel between prosecuting counsel and the prisoner, only the former was notrestrained by the rules that have been developed in later times, and was not led to anticipate them by any regard even to what his audience might consider fair or proper; and the latter could use only such weapons as his natural genius supplied him with at the moment. The result was that with Coke and Raleigh as the combatants, and with the life of the latter and the fortunes of both at stake, the proceedings rose to a pitch of dramatic interest which in later and more formal times can never be approached.

But in all the hurly-burly of passionate invective, of suspicions treated as facts, and of legal doctrines expressed in ill-digested allusions, two main principles may I think be detected. In the first place it was recognised that all the questions raised were to be solved by a law that existed, though no one seems to have felt it necessary that any careful enquiry should be made into what that law prescribed; and secondly, what is of more interest, that the guilt of the prisoner was to be decided on the evidence that was laid before the jury. I do not say that the trial was a fair one, in any sense of the word, in fact I fully agree with the universally held view that it was very much the reverse. But I think that a careful reader must come to the conclusion that every one concerned had essentially the same ideas that we have as to what 
fairness in such matters is, though for the worst of reasons they gave no effect to them. The Court no doubt intended that Raleigh should be convicted, and he never had a chance of escape. But if later generations rose to better things, this was done by developing lines of thought which can be traced back continuously to a period far anterior to 1603 , and which lead us through this trial on their way. The real interest of the trial therefore, apart from personal questions which I will leave over for the present, is that it, affords us a view of the foundation on which the superstructure of our criminal procedure, in the widest sense of the word is based. It excited the highest possible degree of interest at the time, all the actors in it acted from the strongest possible motives, and the anonymous persons to whom we owe the reports of the trial no doubt appreciated the importance of the occasion. It is therefore worth while to treat the trial as a naturalist treats a section of some organisation that he wishes to study, and to consider what details are of historic interest and how far they throw a light on the course of judicial proceedings of an earlier or later date.

The first of these to be mentioned, though it is not the most important, is that with one exception all the evidence in the case was contained in what may be considered depositions, namely, the written account of statements made generally, it seems, to members of the Court, by persons whom it was thought desirable to examine. In the trials that have survived to be published in Howell this seems to have been the usual course, as may be seen in the cases of the Duke of Norfolk in $157 \mathrm{I}$, John Udall I 590, and Weston, whose trial in 16 I 5 , formed the foundation of the trials that took place in connection with the murder of Sir Thomas Overbury, culminating in those of the Earl and Countess of Somerset. Nor was such a course open to the same objection at that time as it would be to-day; for as may be seen in the Popish Plot trials 
nearly eighty years afterwards, if you cannot crossexamine a witness it is not of much use to be confronted with him, and cross-examination was practically an unknown art till counsel were allowed to appear for the accused, or possibly till even a later date. Trials on written evidence are in fact a better means of justice than we are apt to suppose, as may be seen in more than one system of judicature at the present day. In Raleigh's case, however, the system was seen at its very worst, largely because it led up to the point round which centred the grossest part of the injustice that characterised the whole. Cobham was as I have said the only witness of any importance whatever, and everybody knew that he was as bad a witness as it was possible to have. He was an accomplice, he had retracted his evidence, and he was awaiting his own trial. No more need be said of him. But the question pressed heavily on the prosecution how to resist Raleigh's demand that he should be produced, the force of which could not be gainsaid on the merits. The truth of the matter lies in Popham's celebrated answer to Raleigh reported as follows: "Raleigh. The common trial of England is by jury and witnesses. L.C.J. No, by examination; if three conspired treason, and they all confess it; here is never a witness, yet they are condemned." Raleigh had previously referred to Statutes I Edw. VI, c. I2, s. 22, and 5 and 6 Edw. VI, c. I I, s. I2, which provided that a person should not be convicted of treason without two witnesses against him, who should be brought before him at the time of his arraignment, and avow what they had to say against him. Popham replied to this that those Statutes had been repealed, and by the remark I have quoted meant that the trial was to be by the Common Law, and that this did not need witnesses. The ruling was dishonest because, in the first place, it placed an interpretation on what he no doubt regarded as the repealing Act, which even at that time must surely have been considered as fantastically strained, 
and because he must have wilfully suppressed a provision in the Act he referred to. That Act was $\mathrm{I}$ and $2 \mathrm{Ph}$. and M., c. Io, which by S. 7 enacted that trials for treason should only be had according to the due order and course of the Common Law, which is the section that Popham relied on; but by s. I I of the same Act the provisions of 5 and $6 \mathrm{Edw}$. VI as to the two witnesses being brought forward at the trial were repeated. This section which completely vitiates Popham's position he did not refer to. I need not perhaps say anything more as to Popham's conduct in this matter. But when he talked of the Common Law and witnesses he had a very definite meaning, and a very curious one. His point was that the effect of the Statute he relied on was to substitute the provisions of the Common Law for those of the Statutes of Edward, and the Common Law he referred to was the Common Law which was supposed to have existed in England from the earliest times, and the purity of which, guaranteed as it was by the authority of Scripture, was hardly maintained against the invasion of the Civil Law, that is the Imperial Civil Law, derived from States less blessed than ours such as Rome, Italy, and France, though it too could avouch Biblical authority. The position is clearly and most picturesquely put by Sir John Fortescue in his De Laudibus, written about I 40 years before. He is whole-heartedly for the laws of England, what we know as the Common Law, as against the Civil Imperial Laws, though he knows that comparisons are odious and is not very fond of making them. By the Civil Law then, as described by Fortescue, a question of fact is decided by two witnesses, which means eye or ear witnesses. What they say is taken to be true, and consequently much injustice is done, as was the case with Naboth, and Mr. Fringe, whom his royal pupil will remember, and might, but for the goodness of God, have been the case with Susanna. The French are so much aware of the untrustworthiness of witnesses that in capital cases they confirm their evidence 
by torture of the accused, so as to obtain a confession, which after all is the best of proofs: and of the defects of this procedure Fortescue is as much aware as say any of Voltaire's contemporaries. Compare with this the English system of juries. In a civil case twelve men, in a criminal or capital case (they are much the same) twentyfour men, of good substance and repute, are collected from the neighbourhood. They hear the parties and any witnesses that may be called, and they have their own knowledge of the characters of the accused and the witnesses, and also, I think it cannot be doubted, of the facts of the case. There cannot be a fairer form of trial, and the Prince is duly convinced of the fact. It is not opposed to the word of God as revealed in St. John viii. I7, "it is written in your law that the testimony of two men is true," and Matthew xviii. I6, "If thy brother will not hear thee then take with thee one or two more, that in the mouth of two or three witnesses, every word may be established," because the greater is included in the less, and the law of England never decides a case by witnesses only when it can be decided by a jury.

This is not the place, I am certainly not the person to discuss, how far Fortescue's brief summary is correct. As history I understand that it is as full of faults as it is possible for it to be. Legally he represented enlightenment and progress to an astonishing degree, and while the passages I have referred to may make him appear as one still in the ways of darkness, the whole treatise is in many ways almost prophetical of the future.

The opinion on the matter that may be imputed to Popham is expressed by Sir James Stephen as follows: "If a trial by witnesses according to all the rigour attributed to the Civil Law was not to be insisted upon, the only alternative was that the jury should form their opinion as they could, whether upon their own knowledge or upon any sort of materials which might be supplied to them, of which materials the examination of the accused 
would probably be the commonest and most natural. It should be observed that the remarks of the Judges, and especially the illustration given by Judge Warburton, as to a murder being proved by the fact that the prisoner was seen with a bloody sword in his hand leaving the room where the murder was committed immediately after the crime, shows that the Judges of that day recognised no distinction between different kinds of evidence, except the distinction between the evidence of an eyewitness to the actual crime and everything else. They seem to have thought that if the evidence of two such eye-witnesses could be dispensed with, no other line could be drawn," and that in fact the jury were left absolute and might decide on anything they saw fit to consider evidence. Now what I am concerned with is whether the view that Popham found it convenient, or one might say necessary to express at the moment was in any way justified. And I fear that I must come to the conclusion that if he had expressed it I 50 years before he would have deserved the charge of being a reactionary sinning against the light that was then plentifully available. The idea of a trial by witnesses, in the sense of that term described by Fortescue, was surely archaic in the seventeenth century, and I cannot consider that Popham's reference to it, as I take it to be, was much more than a learned jest, used to defeat an unlearned prisoner, who had all the claims that might be derived from law and justice on his side.

It is impossible to say how far a right in the accused man to be confronted with the witnesses against him was generally recognised in the sixteenth century. In minor cases, where no examinations would be taken, I think it must have been the rule that this should be done, and the practice seems to be recognised in Smith's Commonzwealth, written in Queen Elizabeth's time. After I640 the rule that the witnesses should be produced seems to have been established. This may be attributed to the dislike of all 
the ways of the Star Chamber that Charles I's misuse of that Court had provoked; but as the reason and humanity of the practice came to be recognised it was attributed to the "good old laws of England," that is the Common Law, and historical truth was, not perhaps for the first time, sacrificed to patriotism.

The modern reader of Raleigh's trial is struck by the fact that he had no assistance from counsel. He likewise would not have been allowed to call witnesses had he wished to do so. I doubt if either of these injustices as we may consider them actually did him much harm, but he shared them with all other persons accused in ordinary courts. They were defended by the argument that the case against the accused had to be completely proved. If this was done no witnesses or counsel on the other side need be attended to ; if it was not done none were needed. The simplicity of this reasoning disarms modern criticism. A practice more consistent with modern ideas was introduced at the end of the seventeenth and the beginning of the eighteenth century, and completed by the practice of the latter century and eventually by a Statute of 6 and 7 Will. IV, when a prisoner accused of felony was allowed to make a full defence by counsel. The existence of a series of Statutes unluckily makes it impossible to credit the Common Law with this advance.

The only other legal point that I need notice is that I have throughout spoken of the evidence in the case. Accepting the rule that the facts in the case were to be proved by examinations, depositions as I have called them, I think that all that can be considered to have been attempted to be proved were the facts alluded to at Cobham's first confession, and that Cobham went from Raleigh's room to see Lawrency, which was not denied. Everything else, whether in any degree relevant or not, may be neglected on the ground that it was hearsay; not because of any technical rule on that subject, but because it came within the mischief which that rule is framed to 
prevent. The wisdom of that rule has been doubted by authorities whose opinions are entitled to consideration. A reference to many passages in this trial will afford a good practical argument in its favour. The matter, however, was not noticed, and it is in later times that we must look for the foundation of the rule that what the soldier said is not evidence.

This brings me to the last matter that I have to notice, namely, the purely personal questions that arise in the trial. They are perhaps the most interesting feature of the case; but I feel quite incapable of doing justice to them. As regards Raleigh himself I am confined to one aspect of his career, namely, his conduct as an accused person. What cause he had given for the suspicions of the Government, I cannot say, but as I have said he was defending himself against a charge that had no legal foundation, before a Court that was determined to convict him against all considerations of justice. The occasion was one in which courage, resource, patience, and alertness were continuously required, and Raleigh displayed them all in the highest degree. His dealings with Cobham and Aremberg no doubt left weak points in his defence; but he never lost his head, he never gave way; and throughout he never ceased to urge his real defence. He was substantially and essentially in the right, and his conduct was consistent with the best that has been said of his character.

Of Popham I have said more than I wish it were necessary should be said at all.

Two other great figures remain. Contemporary and subsequent opinion have passed a judgment on the conduct of Sir Edward Coke, that has never been questioned. His vituperation of Raleigh is an unparalleled example of forensic brutality; and the law courts show nothing approaching to it till we come to the time of Jeffreys. His method of dealing with the evidence was as unfair as it was possible for it to be. It seems to me impossible to doubt 
that he was fully aware of the weakness of his case, and that he deliberately availed himself of Raleigh's unpopularity and the subservience of the Court to political considerations to create an atmosphere in which full effect might be given to it. His opening speech, as reported, affords some indications of the profound learning which has never been disputed, and also for that love of technicalities which he shared with so many of his contemporaries and of his fellow lawyers of all time, that does not escape the imputation of pedantry. His conduct of this trial is unluckily the best known of his appearances as an advocate, and gives no indications of that resolute independence which he was to display later on a wider stage. But it must be admitted that it leaves a stain on his reputation that nothing can remove, and forms a leading example of that subservience to base motives which it is the pride of his profession to have escaped from.

Lastly I must ask what is to be said of Robert Cecil? Taking the trial by itself he appears in the rôle of a friend reluctantly yielding to the force of the evidence. That he disapproved of Coke's behaviour is pretty plain. But did he really believe that Raleigh was guilty? or did he consider that though his guilt was not proved his conviction was necessary for the safety of the State? and if so was he chiefly responsible for the trial and the miscarriage of justice that it produced? I can only ask the questions which have, I think, all been put before and answered in various ways. If any final answer is forthcoming it must depend on sources that are beyond my views, but speaking merely as a reader of the trial I may hope that Cecil's interventions were as nearly as may be really what they appear to be.

This is all I have to say of the trial. May I draw my own moral from it? Raleigh was unjustly and wickedly convicted by the highest officers of the State exercising their most solemn functions. Of the many men who have been unjustly convicted he was perhaps the most 
illustrious. We have learned better since his day, and have created a system of justice of which we have real reasons to be proud, but how have we done it? To my mind the answer comes as clear as clear can be. We have done it by studying our law continuously, diligently, honestly, and with such ability as was ours, for let us say Iooo years. Each generation has preserved from its inheritance most of what was good, much that was useless, and some at least of what was bad, but the process of growth has never ceased, and I should so far boast of my country as to say that our faces have ever been turned to the light.

Just comparisons are not odious in that they are necessary. In comparing ourselves with our ancestors we are apt to be unjust, because we forget how much of our merits we owe to them. It is more just, because more instructive, to compare our institutions with those of other countries; and if this is done there are few periods at which we need fear the result. The great stream of law flows with a depth that conceals much, but it throws up waves, generally turbid enough, that indicate its course. Raleigh's trial was such a wave, consistently with his character. It was a tragedy for all concerned; it is a disgrace to English law. But it has always served as a warning of what is to be avoided, and the more closely its details are studied the higher will be the estimate we shall form of the history of our legal institutions from the dawn of history to the present day. 